\title{
Lead Extraction
}

National Cancer Institute

\section{Source}

National Cancer Institute. Lead Extraction. NCI Thesaurus. Code C80437.

The removal of one or more lead wires from the heart in a patient with pacemaker or implantable defibrillator. 